\title{
TRACHOMA AS AN AETIOLOGICAL FACTOR IN GLAUCOMA*
}

BY

\author{
H. V. NEMA, H. SAIDUZZAFAR, K. NATH, AND B. R. SHUKLA \\ A.M.U. Institute of Ophthalmology, Gandhi Eye Hospital, Aligarh, India
}

TRACHOMA is one of the major causes of blindness, especially in the East. The common sequelae of corneal involvement by trachoma are only too well known, but the hypertensive aspect of the trachomatous process leading to blindness has not been adequately explored. Conflicting reports have appeared in the literature regarding the relationship of trachoma and ocular hypertension. Müller (1900), de Wecker (1900), Cuénod and Nataf (1930), MacCallan (1936), Adamantiadis (1937), Sédan (1939), Bietti (1947), and Boles Carenini and Cambiaggi (1957) have reported a higher frequency of glaucoma among trachomatous than among non-trachomatous subjects. On the other hand, Guarino (1914), Lagrange (1922), Bailliart (1928), Terson (1928), Trantas (1937), and Pasino (1957) have said that the two conditions are independent. In view of the paucity of reports from India where trachoma is rampant and poses a serious national health problem, and the inconclusive results obtained in other countries, the present work was undertaken to find the relationship between trachoma and glaucoma, if any.

\section{Materials and Methods}

Between January and October, 1963, 114 adults who attended Gandhi Eye Hospital, Aligarh, mainly for complaints arising from trachoma and 41 non-trachomatous adults were investigated. Most of the trachomatous subjects were in Stages III and IV (WHO, 1962). In all 225 trachomatous and 82 non-trachomatous eyes were examined. These were first assessed for the presence and stage of trachoma, especially in respect of corneal and limbal involvement, and were then investigated in the glaucoma clinic by the following methods:

(a) Biomicroscopy, to record the number of visible aqueous veins, using $20 \times$ magnification of the Haag-Streit slit lamp;

(b) Funduscopy;

(c) Applanation tonometry, using the Goldmann applanation tonometer;

(d) Schiötz tonometry;

(e) Gonioscopy with the Goldmann contact lens, grading the angle according to the method of Scheie.

The data thus obtained were subjected to statistical analysis to assess the significance of the trachomatous process in the development of glaucoma. 


\section{Aqueous Veins}

\section{Results}

The number and location of the aqueous veins in each eye were recorded and the average number per eye was calculated for each group. The difference is significant (Table I).

TABLE I

FREQUENCY OF AQUEOUS VEINS IN NON-TRACHOMATOUS AND TRACHOMATOUS EYES

\begin{tabular}{|c|c|c|c|c|}
\hline \multirow{2}{*}{ Group } & \multirow{2}{*}{$\begin{array}{c}\text { Total No. of } \\
\text { Eyes }\end{array}$} & \multicolumn{2}{|c|}{ Total No. of Aqueous Veins } & \multirow{2}{*}{$\begin{array}{l}\text { Standard } \\
\text { Deviation }\end{array}$} \\
\hline & & Total & Mean per Eye & \\
\hline Non-Trachomatous & 82 & 112 & $1 \cdot 366$ & $\pm 1 \cdot 648$ \\
\hline Trachomatous & 225 & 204 & 0.907 & $\pm 1 \cdot 217$ \\
\hline
\end{tabular}

\section{Intra-ocular Pressure}

The average ocular tension in trachomatous and non-trachomatous eyes was $14.978( \pm 4.964)$ and $13.560( \pm 1.814)$ respectively. Comparison of the tension range of the two groups, using applanation values, showed that seventeen of the 225 trachomatous eyes had tensions above $20 \mathrm{~mm}$. $\mathrm{Hg}$, whereas in all the 82 nontrachomatous eyes the tensions were below $20 \mathrm{~mm}$. Hg (Table II). Even the eyes with normal tensions in the trachomatous group had a higher mean level than the non-trachomatous eyes. Values below $10 \mathrm{~mm}$. Hg were neither significant nor sufficient for comparison in the two groups.

TABLE II

RESULTS OF APPLANATION TONOMETRY IN NON-TRACHOMATOUS AND TRACHOMATOUS EYES

\begin{tabular}{|c|c|c|c|c|}
\hline \multirow{2}{*}{$\begin{array}{l}\text { Ocular Tension } \\
\text { (mm. Hg) }\end{array}$} & \multicolumn{2}{|c|}{ Non-Trachomatous Eyes } & \multicolumn{2}{|c|}{ Trachomatous Eyes } \\
\hline & No. & Per cent. & No. & Per cent. \\
\hline Below 10 & 1 & $1 \cdot 2$ & 1 & $0 \cdot 4$ \\
\hline $\begin{array}{l}10-15 \\
16-20\end{array}$ & $\begin{array}{l}67 \\
14\end{array}$ & $\begin{array}{l}81 \cdot 7 \\
17 \cdot 1\end{array}$ & $\begin{array}{r}152 \\
55\end{array}$ & $\begin{array}{l}67 \cdot 6 \\
24 \cdot 4\end{array}$ \\
\hline Above 20 & 0 & 0 & 17 & $7 \cdot 6$ \\
\hline $\begin{array}{l}\text { Mean } \\
\text { Standard Deviation }\end{array}$ & \multicolumn{2}{|c|}{$\begin{array}{l}13 \cdot 56098 \\
\pm 1 \cdot 8139\end{array}$} & \multicolumn{2}{|c|}{$\begin{array}{l}14.97778 \\
\pm 4.9640\end{array}$} \\
\hline
\end{tabular}

\section{Gonioscopy}

Amongst the trachomatous eyes eighteen ( 8.0 per cent.) had a closed angle (Grade IV), while all the non-trachomatous eyes had an open angle (mostly Grade I). There was a tendency for heavier trabecular pigmentation (Grades III and IV) in trachomatous eyes (Table III, opposite), as well as a significantly greater tendency for goniosynechiae. The frequency of iris processes was greater in the nontrachomatous eyes (Table IV, opposite). 
TABLE III

APPEARANCE OF THE ANTERIOR CHAMBER ANGLE IN 225 TRACHOMATOUS AND 82 NON-TRACHOMATOUS EYES

\begin{tabular}{|c|c|c|c|c|c|c|c|c|}
\hline \multirow{3}{*}{ Grade } & \multicolumn{4}{|c|}{ Trabecular Pigmentation } & \multicolumn{4}{|c|}{ Angle Width } \\
\hline & \multicolumn{2}{|c|}{$\begin{array}{c}\text { Non-Trachomatous } \\
\text { Eyes }\end{array}$} & \multicolumn{2}{|c|}{$\begin{array}{c}\text { Trachomatous } \\
\text { Eyes }\end{array}$} & \multicolumn{2}{|c|}{$\begin{array}{l}\text { Non-Trachomatous } \\
\text { Eyes }\end{array}$} & \multicolumn{2}{|c|}{$\begin{array}{c}\text { Trachomatous } \\
\text { Eyes }\end{array}$} \\
\hline & No. & Per cent. & No. & Per cent. & No. & Per cent. & No. & Per cent. \\
\hline Nil & 4 & 4.9 & 9 & $4 \cdot 0$ & - & - & - & - \\
\hline $\begin{array}{l}\text { I Mild } \\
\text { II Moderate } \\
\text { III Heavy } \\
\text { IV Very Heavy }\end{array}$ & $\begin{array}{r}29 \\
42 \\
7 \\
-\end{array}$ & $\begin{array}{r}35 \cdot 4 \\
51 \cdot 2 \\
8 \cdot 5 \\
-\end{array}$ & $\begin{array}{r}67 \\
101 \\
39 \\
9\end{array}$ & $\begin{array}{r}29 \cdot 8 \\
44 \cdot 9 \\
17 \cdot 3 \\
4 \cdot 0\end{array}$ & $\begin{array}{r}49 \\
31 \\
2 \\
-\end{array}$ & $\begin{array}{r}59 \cdot 8 \\
37 \cdot 8 \\
2 \cdot 4 \\
-\end{array}$ & $\begin{array}{r}104 \\
72 \\
31 \\
18\end{array}$ & $\begin{array}{r}46 \cdot 2 \\
32 \cdot 0 \\
13 \cdot 8 \\
8 \cdot 0\end{array}$ \\
\hline
\end{tabular}

TABLE IV

APPEARANCE OF THE ANTERIOR CHAMBER IN 225 TRACHOMATOUS AND 82 NON-TRACHOMATOUS EYES. (GONIOSYNECHIAE AND IRIS PROCESSES)

\begin{tabular}{|c|c|c|c|c|c|c|c|c|}
\hline \multirow{3}{*}{ Grade } & \multicolumn{4}{|c|}{ Goniosynechiae } & \multicolumn{4}{|c|}{ Iris Processes } \\
\hline & \multicolumn{2}{|c|}{$\begin{array}{l}\text { Non-Trachomatous } \\
\text { Eyes }\end{array}$} & \multicolumn{2}{|c|}{$\begin{array}{c}\text { Trachomatous } \\
\text { Eyes }\end{array}$} & \multicolumn{2}{|c|}{$\begin{array}{l}\text { Non-Trachomatous } \\
\text { Eyes }\end{array}$} & \multicolumn{2}{|c|}{$\begin{array}{c}\text { Trachomatous } \\
\text { Eyes }\end{array}$} \\
\hline & No. & Per cent. & No. & Per cent. & No. & Per cent. & No. & Per cent. \\
\hline Nil & 79 & $96 \cdot 3$ & 194 & $86 \cdot 2$ & 13 & $15 \cdot 9$ & 73 & $32 \cdot 4$ \\
\hline $\begin{array}{r}\text { I } \\
\text { II } \\
\text { III } \\
\text { IV }\end{array}$ & $\frac{3}{=}$ & $\begin{array}{l}3 \cdot 7 \\
= \\
=\end{array}$ & $\begin{array}{r}24 \\
5 \\
-2\end{array}$ & $\begin{array}{c}10 \cdot 7 \\
2 \cdot 2 \\
\overline{0.9}\end{array}$ & $\begin{array}{r}31 \\
29 \\
9 \\
-\end{array}$ & $\begin{array}{c}37 \cdot 8 \\
35 \cdot 3 \\
11 \cdot 0 \\
-\end{array}$ & $\begin{array}{r}65 \\
65 \\
20 \\
2\end{array}$ & $\begin{array}{r}28.9 \\
28.9 \\
8.9 \\
0.9\end{array}$ \\
\hline
\end{tabular}

\section{Discussion}

Boles Carenini and Cambiaggi (1957) studied the morphology, frequency, and distribution of aqueous veins in trachomatous and non-trachomatous eyes and our findings are in complete agreement with theirs, in that there is a significant reduction in the number of aqueous veins in cases of trachoma (Stages III and IV), but no alteration in their morphology. The reduction in number can be attributed to the perivascular infiltration and subsequent cicatrization by trachoma, which obliterates the aqueous veins along with the perilimbal vessels. This interference with the aqueous outflow leads to a gradual rise in intra-ocular pressure. Bietti (1963) also takes the same view.

The mean ocular tension in the trachomatous group is significantly higher than in the non-trachomatous, none of the latter as against seventeen of the former having a tension above $20 \mathrm{~mm}$. Hg (Table II). Detailed study of individual cases revealed that eighteen eyes (8 per cent.) in the trachomatous group but only two in the nontrachomatous group had established glaucoma.

The narrowing of the angle of the anterior chamber, goniosynechiae, and heavier trabecular pigmentation in trachomatous eyes appear to be due to the inflammatory 
involvement of the limbus and cornea during the active trachomatous infection, which may cause a subclinical toxic or allergic reaction in the angle. The trabecular pigments may have been dispersed from the iris root.

Contrary to the observations of Larmande and Coulliaud-Maisonneuve (1955), iris processes were less numerous in the trachomatous eyes in our series. This cannot be taken as conclusive, however, as goniosynechiae may have obscured them. The number of iris processes cannot be directly related to the trachoma because they are formed at the time of mesodermal cleavage during the development of the anterior chamber.

\section{Summary}

An investigation of 225 trachomatous eyes in 114 individuals and 82 nontrachomatous eyes in 41 individuals by biomicroscopy, funduscopy, applanation and Schiötz tonometry, and gonioscopy revealed that the trachomatous eyes had a higher mean ocular tension, a lower average number of aqueous veins, a narrower anterior chamber angle, heavier trabecular pigmentation, and an increased tendency to the formation of goniosynechiae.

It is suggested that trachoma predisposes towards glaucoma by producing obstructions to the aqueous outflow.

We gratefully acknowledge the facilities provided by the Trachoma Research Centre (Indian Council of Medical Research) in the course of the study.

\section{REFERENCES}

Adamantiadis, B. (1937). Rev. int. Trachome, 14, 241.

Bailliart, P. (1928). Bull. Soc. franç. Ophtal., 41, 323.

BIETTI, G. B. (1947). "Il Tracoma." Alto Commissariato per l'Igiene e la Sanità Publica, Roma. (1963). Personal communication.

Boles CARENINI, B., and CAmbiagGI, A. (1957). Rev. int. Trachome, 34, 62.

CuÉNOD, A., and NATAF, R. (1930). "Le trachome." Masson, Paris.

GUARINO (1914). "Studio critico sull'evoluzione tracomatosa." Cairo. (Cited by Boles Carenini and Cambiaggi, 1957).

Lagrange, F. (1922). "Du glaucome et de l'hypotonie." Doin, Paris. (Cited by Larmande and Longo (1960), p. 265).

LaRmande, A., and Couilliaud-Maisonneuve (1955). Rev. int. Trachome, 32, 444.

and Longo, A. M. (1960). Ibid., 37, 1.

MacCallaN, A. F. (1936). "Trachoma", p. 53. Butterworth, London.

Müller, L. (1900). Arch. Augenheilk., 40, 13.

PASINO, L. (1957). Studi sassaresi, 35, 25.

SÉDAN, J. (1939). Cited by Larmande and Longo (1960), p. 265.

Terson, A. (1928). Bull. Soc. franç. Ophtal., 41, 329.

Trantas, A. (1937). Rev. int. Trachome, 14, 131.

WECKER, L. DE (1900). Ann. Oculist. (Paris), 124, 45. (Cited by Larmande and Longo (1960), p. 264).

WHO (1962). Tech. Rep. Ser. No. 234, p. 16. 